\title{
Генноинженерная биотехнология
}

\author{
ร.โK $575.24: 577.352$ \\ TPAНСФОРМАІИЯ ПРОТОПТАСТОВ STREPTOMYCES GRISEUS \\ ХРОМОСОМНОЙ II ПЛАЗМНДНОЙ ЦНК, \\ ЗАКЛЮЧЕННОЙ В ЛИПОСОМЬ
}

А. С. Стенюко, Б. П. Маңелюх, Т. Д. Дехтяренко, Е. Е. Стефанишин,

А. В. Стефанов, ІІ. К. Безкоровайная, J. В. Полищук, Н. Н. Мапковскиї

Введение. В настоящее время липосомы широко прнменяются в биологин и меднцине для решения разных задач. В молекулярно-бнологических и генетнческих исследованиях их иачали применять для введения генетического материала (ДНК, РНК, отдельные хромосомы, клеточные ядра) в животные клетки, протопласты растений ін микроорганизмов [1-7]. Исследования по трансформащип микрооргаиизмов с применением липосом малочисленны и представляют значительный нитерес для генетической ннженери. Мейкинс и др. выполнили работу с исполизованием липосом на Streptomyces cocticolor и $S$. clavuligerts $[6,7]$, Родфорл и др. - на Neurospora crassa [8], Прозоров и др. - па Bacillus sublilis [9]. Получениые нми результаты свидетельствуют о высокой эфф)ективности введения чужеродной ДНК в протопласты и клеткп микроорганизмов с помощыо лиюосом, обсспечивающих надежную защиту ДНК от воздействия пуклеаз и полиостью сохрапяюших се бислогнческую активності $[10,11]$.

Целью настоящей работы явилось выяснение возможности использования лигосом іри трансформации протопластов Streptomyces griseus хромосомной н плазмидной ДНК.

Материалы и методы. В работе использованы следуюцие штаммы стрсптомицетов и бактернй: прототрофный штамм $773 \mathrm{~S}$. griseus, бесплазмидный шитам $68-31$ thi lou $S$. griseus, $S$. lividans $T C 8$, песущий гнбриднуго плазмиду plJ2 $N 0^{\mathrm{r}}$, получснный от 4. Хопвуда (Ангіия), стрептомицет глобнспорніової rруппы S. species 1912, содержащий пиазмиду $p S G 1912 \mathrm{Ant}^{+}$, детерминирующую образоване аитнопотик пензвестной природы, который угнетает рост тест-штама 165 и принадежит $к$ той же группе стрептомицетов, получепнй из музея культур отдсла обпсиі и попвеной микобиологин Ин-та микробиологии и внрусотогин им. Д. К. Заболотного All VССР. Штамм

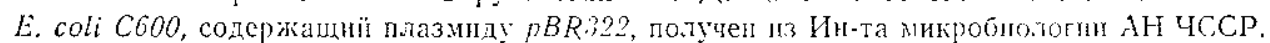
Хромосомную ДНК получали по модифицированному метолу Мармура [13], плазмидпую - по Бирнбойму и Доли [14], а также метолом равновсного псптрифугирования в градиенте плотности $\mathrm{CsCl}$ - этидия бромпда (ЭБ) по Кирби [15].

Для получсии липосом использовали янчный лецитин, вцделенный по методу Бснгхема [16]. Чнстоту лецитина контролнровали посредством тонікослойнӧ̈ хроматографни па пітастиках Silufol UI25t («Kavaliet», ЧCСP) в спстеме хлороформ: метанол: вода $(65: 35: 4)$. В опытах пспользовали пейтральныс липосымы из янчного лецитина, положительн заряженныс липосомы, меморана которых содержала лсцитни и стсарилами ( $7: 1$, моль/моль), а также отрицательно заряжениые липосомы, состолцие из лецитина и днцетилфосфата в соотношенин $7: 1$, моль/моль. Раствор липидов в хлороформе $(20 \mathrm{mr} / \mathrm{мл)}$ вносили в круглодонную колбу н высунивали при пониженио давиенин в роторном испарителе. $\mathrm{K}$ образовавшейся топкой пленке липида тобавляли ДНК в концентрации $14-52 \mathrm{Mкг} / \mathrm{Mл}$ и $185-370 \mathrm{kБK}{ }^{3} \mathrm{H}$-ДНК в буферном растворе (среда Р жля получения протопластов [17]). Для разрушения невключнвшейся ДНК к 


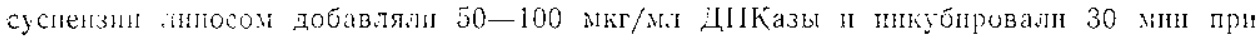

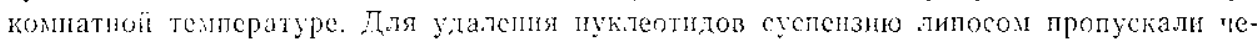

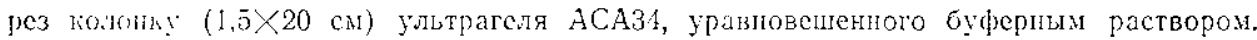

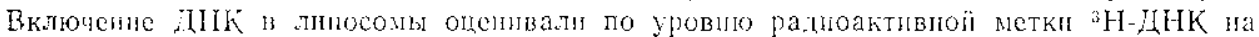

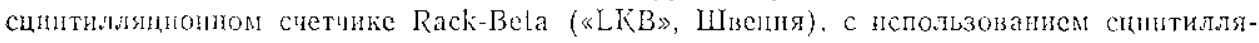
Topa 5per.

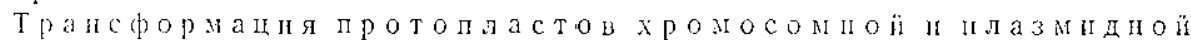

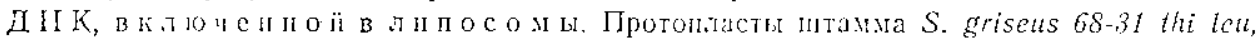

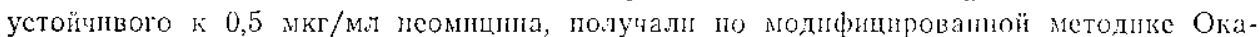
ниши [17]. Трансформацноная смесь состояла из ранынх обтемов (по 0,2 м.1) протопластов $\left(10^{\circ}-10^{\circ}\right.$ клеток в 1 м.л) и лнпосон, пагруженных ДНК (10: везнкуі в

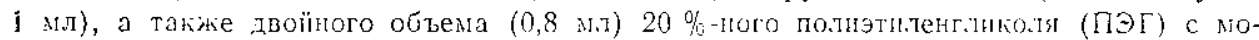

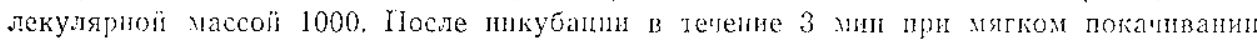

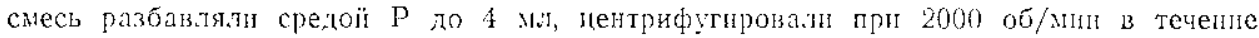

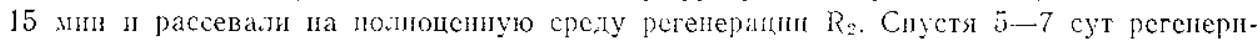
ровавшис колони отсевали па полноценную среду тотанно и вырапнвали до получеиня обнльнй спорулдни, а затем проводили генетнеслиї анализ регенерантов. Для выделения трапсформалтов по хромосомиым маркерам в среды добавляли факторы роста тнамин и лейцин; клоны, трансформированыс $p / J 2$, отонрали на средах, содержаних 10 и 30 мкr/м.т неомицна. Тралсформанты, полугенные с понощыо плазмндной ДНК $p S 61912$, идентифиниова.ли средн колоний регенерантов па сосвой среде препенатыванием на газол со штаммом тест-культуры 165.

Результаты и обсуждение. Меченная ${ }^{3} \mathrm{H}-$ ДНК $p B R 322$ взята нами как модельная для изучения взапмодействия пипосои с различным зарядом п ДНК. Установлено, что включение ДНК завнсит от заряда мембраны липосом. Напболее высокий процент включения меченой ДНК отмсчался в положителыно заряжениые липосомы иі составјял $8 \%$ нсходного количества ДНК, тогда как в нейтралыные лиюосомы включался $1,6 \%$ ДНК, а в отрицате.льно заряжениые - 0,8\%. Результаты трансформацин хромосомной и плазмидной ДНК, заключенной в липо-

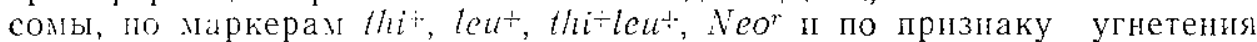
роста тест-интамма (образование зон) представлены в таблице. Расчет частоты трансформации проводнли по отношению получениых трапсформаптов к инслу проверенных, тотально отсеяниых колопий регенерантов в опытах с пипосомами и включспной ДНК. Ошио̆ку выниляли по Ilуассону.

Как видно пз таблицы, трансформация протопластов хромосомной ДНК, заключениой в липосомы, проңсходнт с высокой частотой, которая на 2--3 порядка выше частоты трапсформация с помццю ДНК, используемой без линосом. Частота образования одинарных и двойных трансформаптов была одного порядка и практически не зависела от

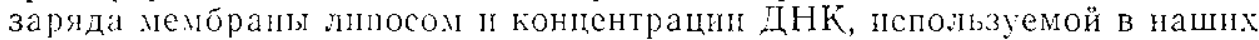

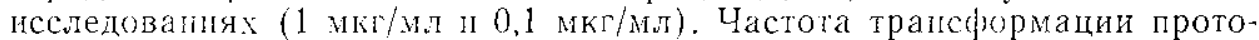
пластов с помощью ДНК pSG1912 и липосом по прнзиаку угнетения роста тест-штамма 165 (рис. 1) составляла $2 \cdot 10^{-1}$ на $1 \mathrm{mkr} / \mathrm{mл}$ ДНК, тогда как при пспользовапни плазмидной ДНК без линосом она составляла $3 \cdot 10^{-3}$, что на два порядка пиже опытной. Всего выделено 439 клонов, 20 из которых были изучены бнохимически для выявления плазмиды $p S G 1912$. Все 20 проверенных клонов стабнльно в течение 6-7 генераций сохраняли плазмидную ДНК, которая по скорости движения в агарозном геле соответствовала характеристикам плазмиды $p S G 1912$ (pıс. 2). Необходимо отметить, что плазмидную ДНК выделяли только fіо методу Бирнбойма іп Доли, попытка выделить плазмиду методом равновесного центрифугирования в градиснте плотности $\mathrm{CsCl}$ - ЭБ была безуспешной. ІІри храпении получениых клонов в течение 12 генсращий в лабораториых условиях у ряда трапсформанттов плазмиду выделить ие удалось, хотя фенотип их сохранялся.

Ото́ор неомиципустойчнвых клонов, полученных при использовании ДНК плазмиды pIJ2, осуществляли методом пепрямой селтекции с последуюцим отсевом па среды с неомнцином в концентрации 10 і 
30 мкг/мл. Среди 1424 проверенных регенерантов было получено 232 клона, устойчнвых к неомицину, т. е. тастота появления псомицинрезнстентиых клонов составляла $2 \cdot 10^{-1}$ па $1 \mathrm{mkг/m.7} \mathrm{ДНК,} \mathrm{тогда} \mathrm{как} \mathrm{:}$ контроле без использования пипосом она была $3 \cdot 10^{-3}$. Из указанных

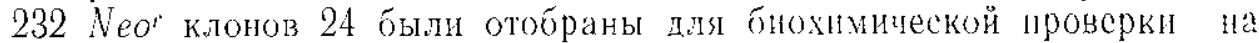
палпчие п.лазмиды p/J2. В резуиьтате проведениого скринипга плазмида plJ2 обнарудена только у двух кілонов. Наличие плазмиды р/J2 подтверждалось каждой нз проверок в течение семи генераций (рис. 3). При дальнейем хранения этих клонон в течепюе $11-12$ генерапий фенотип пх сохранялся, но плазмиду выделить, не удалось. Это, по-видниому, связано
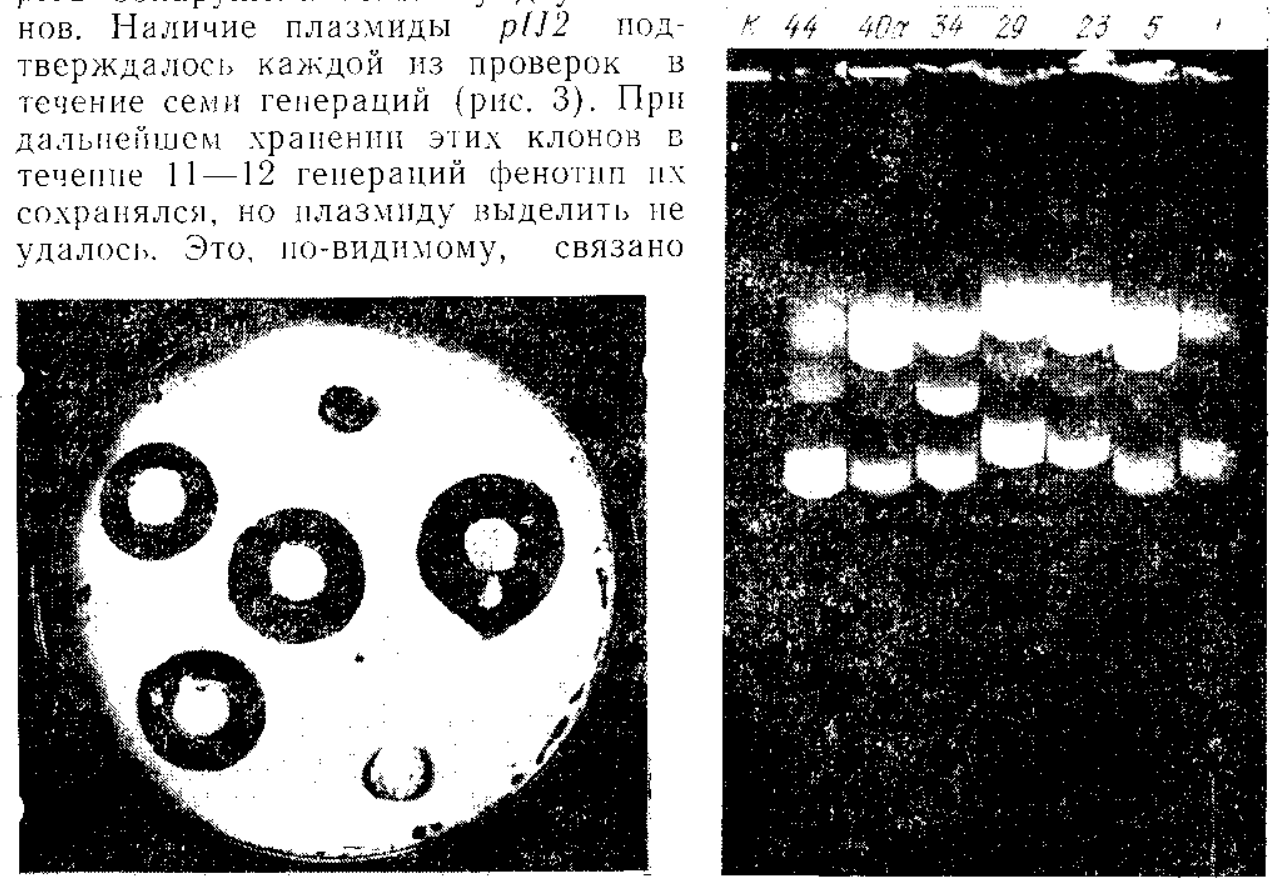

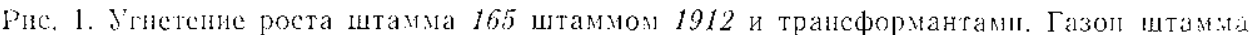
165, на который наложены arapoвые блоки с выросшими культурами: справа - пाтамм

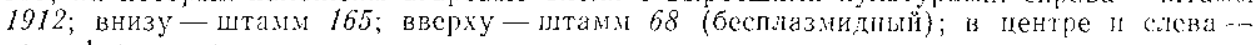
т ралісформанть.

Fig. 1. Inllibition of strain 165 growll by strain 1912 and transformants. Plate wit: culture of strain 165, where agar blocks with grown cultures are superposed: on the right - strain 1912, in the lower part - strain 165 , in the upper part--strain 68 (withert plasmid), in the centre and on the leit - transformants.

Рнс. 2. Электрофорез в агарозном геле пренаратов плазмндой ДНК, выделенной :: штамма реципиента $S$. grisets $68-31$, трапсформалтов $44,40 a, 34,29,23,5,1[2-8]$.

Fig. 2. Agarose gel electroplioresis in the preparations of plasmid DNA isolated from: transformants: 1 - strain-recipient $S$. griseus $68-31 ; 2-8$ - transformants $44,400,34$, 23 $22,5,1$.

со встранванием глазмнды в хромосому трансформанта, что и по тверждается длительным сохранением маркера неомицинустойчцвости, детерминированного ллазмидой pIJ2. Высокая частота трансформации протопластов стрептомицетов с помощью хромосомноч ДНК, заключенюй в липосомы, показана у $S$. coelicolor и $S$. clavuligerus $[6,7]$. В этих трансформационых системах ауксотрофные и прототрофные штаммы поочередно служили и донорами, и реципнентамн. Әффективность трансформации по маркерам прототрофностія и антцбиотикорезистентности была одинаково высокой и составляла $10 \%$. тогда как Ііо маркерам ауксотрофности экспрессировалось только 2 $4 \%$ колоний. Возможно, такая высокая частота трансформации связана с тем, что авторы для получения липосом использовали фосфолипиды, изолированные из клеточной степки этих же стрептомицетов. Использовапие в паших исследованиях фосфолипядов другой природь позволило получить такой же высокий уровень трапсформации, так хто, по-видимому, прирада фосфолипидов пе играет такой важной роли $\mathrm{E}$ эффективности трансформации. Очевидно, определяюшим здесь явля- 
ютея пиносомы как пнструмент для введсния и зациты ДНК. На первых утанах работы с липосомами мы использовали смесь липосом п цНК (контрель 1), п частота трансформацин в этон сыучае была па уровлс пастот трансформанин с номощью одной ДНК без линосом

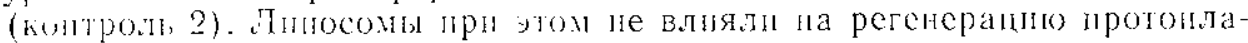

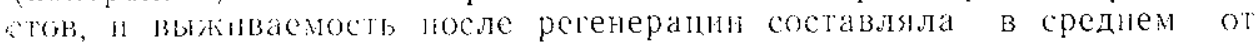

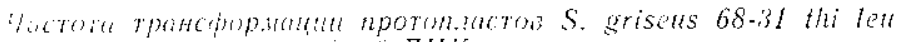

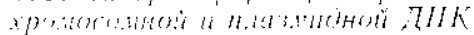

Fregulaty of the transformation of probuplasts of S. wrisens $68-31$

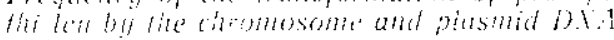

\begin{tabular}{|c|c|c|c|}
\hline 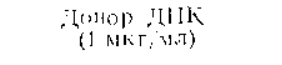 & 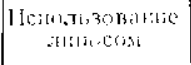 & 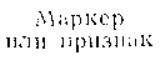 & 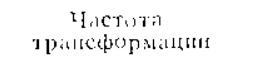 \\
\hline 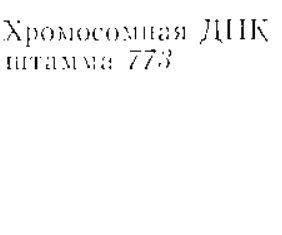 & $\begin{array}{l}\vdots \vdots \\
\vdots \\
\vdots \\
- \\
- \\
-\end{array}$ & 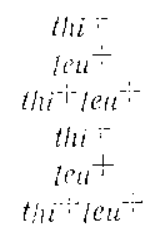 & $\begin{array}{c}1 \cdot 10^{-1} \pm 0,000 \\
6 \cdot 10^{-2} \pm 0,005 \\
1 \cdot 10^{-1} \pm 0,007 \\
\text { HeT } \\
1,8 \cdot 10^{-4} \pm 0,0002 \\
\text { HeT }\end{array}$ \\
\hline 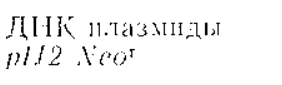 & $\begin{array}{l}\frac{1}{1} \\
-\end{array}$ & Heor & $\begin{array}{l}1,8 \cdot 10^{-1} \pm 0,007 \\
8 \cdot 10^{-3} \pm 0,0001\end{array}$ \\
\hline 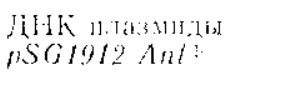 & $\therefore$ & Ant :- & $\begin{array}{l}2 \cdot 10^{-1} \pm 0,0001 \\
3 \cdot 10^{-3} \pm 0,0002\end{array}$ \\
\hline
\end{tabular}

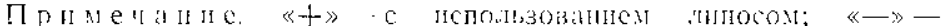
$6032114 x$

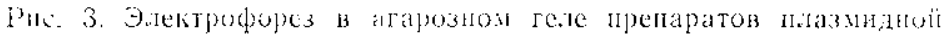

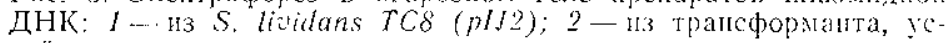

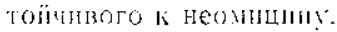

Fig. 3. Agarose gel clectrophoresis of the plasmid DNA preparalims: 1. from strain $S$. libidans TC8 (pl/2) Neor: 2 ... from fransformant $\mathrm{Neo}^{5}$.

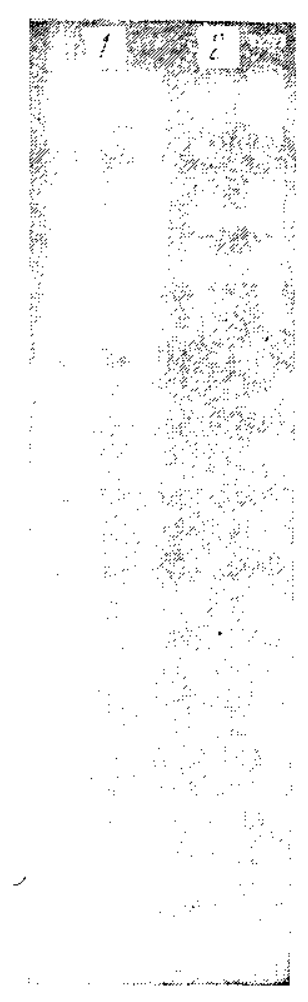

$4 \cdot 10^{4}$ до 5-6.105. При трансформанин протопластов лизатом клеток қак источником свободной LНК по хромосомным маркерам у $S$. paruius также получена высокая частота трансформации [19]. B паших исследования пастота трансформацин практически не отличлас, при псползованни положительно и отрпиательно заряженных линолы, хотя ранее Ларквнн $[3,20]$ при введенин ДНК плазмиды $p B R 322$, меченной "Н-тнмиднном, в протопласты листьев табака с помонью лниосом показал, что папболее эффектишыми являются положительпо заряженные

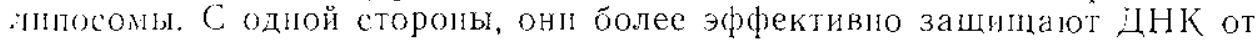
дейстия нуклеаз, а с другой - обладают более высокой ДНК-связыва-

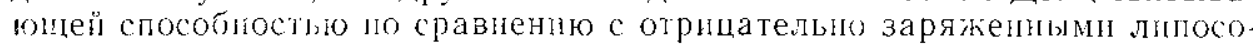
мами, что позволяет нспользовать более низкие копцентрации нуклениовых кислот н своднт к минимуму структурные и метаболические повреждения протопластов прн взанмодействни с пниосомами. Молеку тярныс механизмы поглощения LLНK, заключенной в липосомы, пзучены педостаточно, однако на основани высокой частоты трансформацин, получениой в экспериментах с примененем липосом, можио предположить, что лнпосомы в данном слунас функционируют как искусствениые протопласты, п здссь паблюдается процесс, аналогичный их слияпию. Сиачала пронсходнт слияние меморан липосом и протопластов, а затем слияне и смешнвание содержимого; при этом генетический материал не подвергается разрушенпю пз-за огсутствия нуклеаз перпплазматического пространства клетки $[21,22]$.

Мейкннс [6] на основании собственных н литературных данных пришсл к заключению, что в липосомы заключается ДНК с молекулярной массой $8-10 \cdot 10^{6}$ в количестве, эквпвалентиом 3-5 копиям генома. 
Таким образом, с помощью хромосомной и плазмидной дыК, заключенюй в лппосомы, осүществлена трансформация протонтастов S. griseus, которая по әффективності была на $2-3$ порядка выне контрольной без нспользования. типосом.

\section{TRANSIORMATION OF STREPTOWYCES GRISEUS PROTOPIAASTS BY CHROMOSOMAL $A N D$ PLASHID DNA INCAPSULATED IN LYPOSOMES}

A. S. Stenko, B. P. Mutscilykh, T. D. Dekhtyurenko, E. E. Stephanishin, A. V. Stefanoi, N. K. Bezkoroininaya, L. V. Polishchuk, N. N. Hashkoisk!!

D. K. Zabolotny Institute of Microbiology and Virology,

Academy of Sciences of the Ekrainian SSR, Kiev

\section{Sum ary}

S. griscus protoplasis are transformed by cliromosonal and plasmid D.A incapsulated in liposones. The irequency of transformation by cluromosomal markers ui prototrophity and by plasmid marlers of resistance to neomycin and the formation of growth inhibition zones by means of DNA incapsulated in liposomes was iwo-three orders higher in comparison with control DN.1 without liposones.

Plasmid DNA was isolated irom transformants and renained stable for 0.7 generations, phenotype being unchanged for 12 generations.

1. Ostro M. D., Gincomoni D., Drey S. Incorporation of high molecular weight RNA into large artificial lipid vesicles// Biochem. and Biopliys. Res. Communs, -- 1977,-76, N 3. - P. 836-842.

2. Dimitriadis G. Entrapment of plasmid DNA in liposomes // Nucl, Acids Res. -- 1979.6. N 6. - P. $2697-2705$.

3. Lurguin P.F. Binding of plasmid loaded liposomes to plant protoplasts validity of

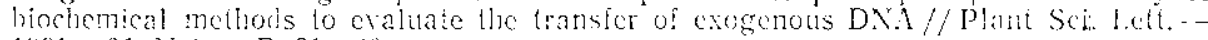
1981.-21, N 1. - P. 31--10.

4. Introduction of liposone incapsulated SV-40 DVA into cells/R. Fralcy, S. Subramary, P. Bcrg, D. Papahadjopuolos// J. Biol. Cien1. - 1980.265, N 2i. - P. 1013110435 .

5. Liposomemedioted associaion of DNA with plant protoplasts: influence of vesicle lipid composition /F. Rollo, S. Ifancesco, G. Rino, P. Bruno//Plant Call. Cull. $1080 .-2, N 1 .-2$ P. $237-246$.

6. Makins J., Holt G. Liposone-protoplist interaction of microbial product// JEMS

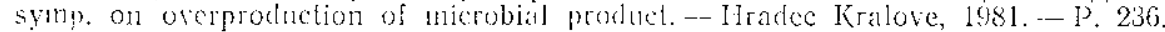

7. Makins $F$, Holt G. Liposome-mediated transformation of Streptomyce's of applied chromosomal DNA / Nature. - 1981.-293, N $5834 .-$ P. $671-673$.

૪. Liposome-mediated genetic transformation of Netrospora crassa / A. Rondford. A. Saz¿i, M. J. Trarer, H. Parisi //Mol. and Gen. Genct.--198i.-184, N 3. - P. 567-671.

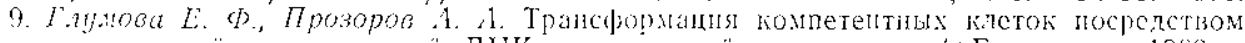

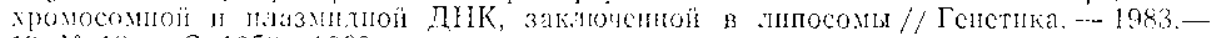
19. № 12. - C. $1958-1963$

10. Willson $T$., Papuhadjopuolos D., Taber $R$. Tilie introduction of polio-virus RNA into

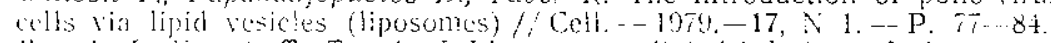

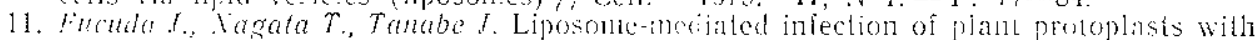

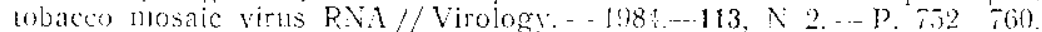

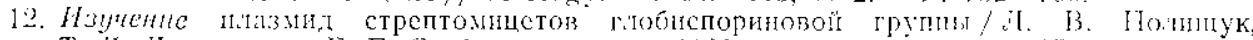

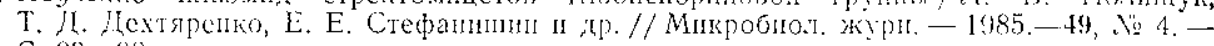
C. $83-88$.

13. Marmat 3. A procedure for the isolation of desoxyribonucleic acid from brieroorganisms // J. Mol. Biol. - 1961.- 3, N 2..- P. 208-218.

14. Birnboim $/ 1$. , Doty $I$. A rapid extraction procedure for screening recombinant plasmid J) NA // Nucl. Acids Res. - 1979.-7, N 6.-. P. 1513-1523.

15. Kirby R., Wollon S. Restriction shutics on the SCPL plasmid of $S$. coeflotor//

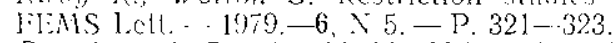

16. Bansham A. D. Hill M. M. Miller M. J. A. Preparation and use of liposomes as models of biological membranes / Methods in membrane biology. - Vew Vorf: plenum press, 1974. - Vol. 1. - P. $1-68$

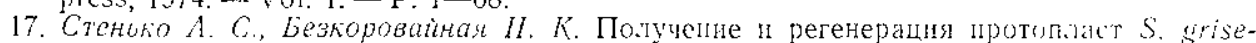

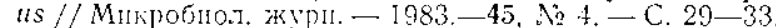

18. Hoperood D. A., Wright H. M. Bacterial protoplast fusion: recombination in fused protoplasts of $S$. coelicolor $/ / \mathrm{MOl}$. and (ien. Genct. $-1978 .-162, \perp 2, \cdots \mathrm{P} .307-317$.

(Oromqante cr. Ha C. 278). 
gels / I. Dretgen, M. Bellard, P. Sassone-Corsi, P. Chambon // AnaI. Biochem.- 1981.112. N 2. - P. $295-298$.

7. Maniatis T. Fritsch E. F. Sambrook J. Molecular cloning - a laboratory manual. Vew York: Cold Spring Harbor, 1982,--545 p.

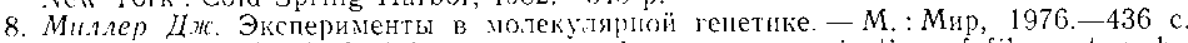

9. Beck E., Zink B. Nucleotide sequence and genome organization of filamentous bacteriophages $f l$ and $f d / /$ Gene. -- $1981 .--16, N 1$. - P. 35-58.

10. Collins J. Deletions, insertions and rearrangements affecting rpoB gene expression // Mol. and Gen. Genel. - 1979.-173, N 1.-P. $217--220$.

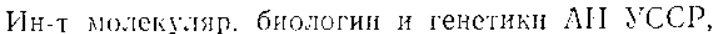

IIo.1yчe!10 15.02 .86 Киев

19. Ochi K. Protoplast fusion//Molecular breeding and genelics of applied nijernorganioms / Eds K. Sakaguedi, M. Okanisli. ... New York Acad press, 1980 .... P 88-94

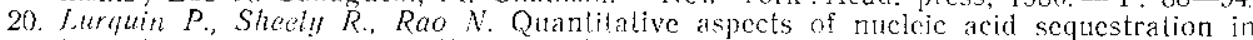
large liposomes and their effects on plant protoplast// FEBS lett. - 1981. -25 , N 2. P. $183--187$.

21. Weisman G., Cohen C., Hoffstein S. Introduction of enzymes by means of liposones,

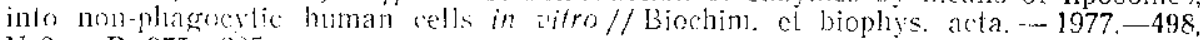
N 2. - P. $375-.385$

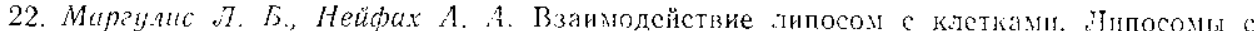

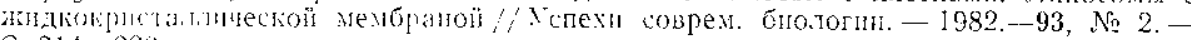
C. $21 !-229$

Нн-т у!кробиміогын и вирусотогин

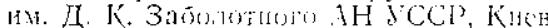

Потутено 22.07 .85 